\title{
On the Non-Adoption of Present Value Depreciation in Managerial Performance Evaluation
}

\author{
Dr. Edward Blocher, Accounting, University of North Carolina at Chapel Hill \\ Dr. Chee W. Chow, The Vern Odmark Professor of Accountancy, San Diego State University \\ Dr. Adrian Wong-Boren, Accountancy, San Diego State University
}

\begin{abstract}
Present value depreciation has long been advocated as a way to improve the dominant return on investment (ROI) managerial performance measure. Yet, to date, reported adoptions of this approach have been rare. Since providing appropriate managerial incentives is increasingly important in this era of intensifying global competition, it is useful to explore why firms are foregoing this theoretically superior approach. This paper points out that the non-adoption of present value depreciation may be an economically rational choice. It notes that advocates of present value depreciation have failed to consider some potentially significant implementation costs. In addition, a small scale computer simulation reveals that under conditions of uncertainty and correlated cash flows, ROI calculated under conventional depreciation procedures can often closely approximate the theoretically correct value. Hence, besides providing a specific analysis of present value depreciation, this study also underlines afresh the importance of cost/benefit considerations in developing or adopting new approaches to business problems.
\end{abstract}

\section{Introduction and Overview}

Return on investment (ROI) has long been the dominant measure of managerial performance in U. S. companies. A survey about two decades ago by Mauriel and Anthony [1966], and a more recent one by Reece and Cool [1978] both found that over 90 percent of the respondent firms used ROI as a key measure of investment center manager performance.

Since ROI relates profits to the investment base used to generate them, this measure would seem to provide comparability across differentsized operations, motivate efficient and effective use of resources on hand, and provide managerial incentives to direct corporate investments in the most profitable directions. However, as many critics have observed, the typical way firms calculate ROI can create significant incentives for managers to act contrary to their firms' interests [Kaplan, 1982, 1983; Anthony, Dearden and Bedford, 1984; Johnson and Kaplan, 1987]. Anthony, Dearden and Bedford [1984, p. 362] observe:

We know from personal experience that the conceptual flaws of ROI for performance evaluation are real and do result in dysfunctional conduct on the part of divisional managers .... however,...few managers are likely to admit its existence and many are unaware of it when it does exist. (Emphasis added)

A major source of ROI's potential disincentive effects is the accounting procedures used in its calculation. Reece and Cool report that most firms compute ROI with the same accounting procedures used for external financial reporting. Because of this practice, the computed ROI for 
most investment projects may diverge from their economic returns, thus inducing managers to make resource allocations that depart from maximizing firm value. Figure 1 illustrates how such disincentives may arise. This example follows the reportedly dominant approach of basing ROI on the net book value of assets.(1) The depreciation methods used in this illustration also reflect common practice. An examination of the firms included in the 1985 Compustat data base (2) revealed that 67 percent of these firms indicated the exclusive use of straight line depreciation for financial reporting purposes. Another 4 percent reported using only accelerated depreciation, while the remaining 29 percent indicated a mix of the two methods.

The numbers in Figure 1 assume an investment project that costs $\$ 21,060$ and is expected to generate three annual cash inflows of $\$ 10,000$ each. The economic (discount) rate of return on this investment is 20 percent, yet as parts 1,2 , and 3 of Figure 1 show, the ROI figures obtained under the common depreciation methods are generally far apart from this value. Furthermore, all of the computed ROI values are depressed relative to the 20 percent rate in the first year, increasing dramatically in years two and three as the net book value of investment is reduced via depreciation. This time pattern provides the basis for claims that ROI, as it is commonly computed, motivates managers to seek out projects with big expected short term payoffs, at the expense of more profitable projects where the expected benefits are either deferred (such as research and development), or are spread out over a long time period.

Part 4 of Figure 1 illustrates how present value depreciation may ameliorate these disincentive problems. Under this approach, depreciation is computed as an investment's loss of present value over a given time period. In part 4 of Figure 1, the number 2.106 is the present value factor for a 3-year annuity at a 20 percent discount rate. At the end of year one, two annual cash inflows remain, with a present value factor at that time of 1.528. Hence, with the passage of the first year, the present value of the project declines by .578 from 2.106 to 1.528 . Accordingly, depreciation for the first year is .578 out of 2.106 , or $\$ 5,780$ out of the $\$ 21,060$ cost. The second and third year depreciation figures are arrived at in a similar manner.

Note that the ROI figures in part 4 are uniform over all three years of the project's duration, and are equal to its economic return of 20 percent. This equivalence suggests that present value depreciation can help to align the interests of managers and their firms.

The concept of present value accounting has been around since at least the 1920s,(3) and has been widely discussed in articles and textbooks. Yet surveys indicate that it is seldom used.(4) Since providing managers with the appropriate incentives is a matter of great current concern [Kaplan, 1983; Johnson and Kaplan, 1987], the absence of this approach in practice deserves scrutiny. This paper points out that supporters of present value depreciation have overlooked some potentially significant implementation costs. In addition, a small scale computer simulation is used to show that under conditions of uncertainty and interdependent projects, ROI calculated with conventional accounting procedures can closely approximate the theoretically correct value. Hence, under certain circumstances, firms may not benefit greatly from adopting the theoretically superior present value depreciation method.

\section{The Potential Implementation Costs of Present Value Depreciation}

Anthony, Dearden and Bedford (1984) and others have observed that the management control process is a closed loop - the results of operations for a given period must be measured, evaluated and acted upon in order to affect ex ante and ex Post managerial actions. This implies that if present value depreciation is to produce its purported incentive effect, it needs to be integrated into the performance evaluation and compensation system. However, doing so introduces the difficult problem of identifying project specific cash flows. When a project is being proposed and evaluated, typically attempts would 


\section{Figure 1}

\section{Hypothetical Capital Investment: Cash Flow, Depreciation, and ROI}

Note: Cost $=\$ 21,6060$ at begining of first year; even cash flows ot $\$ 10,000$ at the end of each year; internal rate of return is $20 \%$.

\section{Depreciation Method}

1. Straight-line balance
3. Sum-of-the-
Year's-Digits

4. Annuity Method
a) Depreciation Expense

$$
\begin{aligned}
& 21,060 / 3 \\
& =7020
\end{aligned}
$$

b) $\mathrm{ROI}$

a) Depreciation Expense

b) ROI

a) Depreciation Expense

b) $\mathrm{ROI}$

First Year

$\frac{10,000-7020}{21,060}$

$=14.15 \%$

14,040
$\underline{10,000-14,040}$ 21,060

$=-19.18 \%$

10,530

$\frac{10,000-10,530}{21,060}$

$=-2.5 \%$

a) Depreciation Expense

$\frac{.578}{2.106} \times 71,060$

$$
=5780
$$

b) ROI

$$
\begin{aligned}
& \frac{10,000-5780}{21,060} \\
& =20 \%
\end{aligned}
$$

Second Year

$\begin{array}{ll}7020 & 7020 \\ \frac{10,000-7020}{14,040} & \frac{10,000-7020}{7020} \\ -21.23 \% & =42.45 \%\end{array}$

4680

2340

$\frac{10,000-4680}{7020} \quad \frac{10,000-2340}{2340}$

$=75.78 \%$

$=327.35 \%$

3510

$\frac{10,000-7020}{10,530} \quad \frac{10,000-3510}{3510}$

$=28.30 \%$

$=184.90 \%$

$\frac{.695}{2.106} \times 21,060 \quad \frac{.833}{2.106} \times 21,060$

$=6950 \quad=8330$

$\frac{10,000-6950}{15,280}$ 15,280

$\frac{10,000-8330}{8330}$

$=20 \%$ 
be made to estimate its incremental cash flow impacts, including those on centrally managed resources like cash and inventories, and shared facilities such as maintenance and data processing. However, once a project is integrated into overall operations, it becomes costly to disentangle its impacts on resource flows from those of other activities. Once the link between actual results and pre-decision analysis becomes broken, the potential motivational effects of present value depreciation may also be lost.

Even if realized cash flows can be unambiguously traced to specific projects, problems of interpretation remain. Investment decisions, by their very nature, are based upon forecasts. Such forecasts are subject to both intentional biasing (e.g., the creation of budgetary slack) and unintentional errors. When realized and projected cash flows differ, the mechanics of present value depreciation require that the depreciation schedule be adjusted. How the resultant "forecast variance" should be treated - as a lump-sum adjustment or spread over the predicted life of the project - becomes an issue. And if predictions are adjusted in light of realized outcomes, the depreciation schedule would also need to be changed. Since forecasts typically involve subjective judgment,(5) ROI computed under present value depreciation would be directly affected by such subjectivity.

When one considers that a firm or division typically would have large numbers of investments, that present value depreciation would require tracing each investment's specific cash flows through time,(6) and that the present value depreciation schedule is subject to both intentional and unintentional forecast errors, it becomes apparent that the implementation costs associated with this approach could be substantial.

The preceding discussion has concentrated on cost considerations. Issues also exist concerning the potential benefits from present value depreciation. The next section presents simulation results that under certain circumstances, ROI based on conventional depreciation approaches do not differ significantly from that based on the present value approach. Hence, the gains from present value depreciation may be limited in certain circumstances.

\section{Comparing ROI Under Present Value and Conventional Depreciation: Some Simulation Results}

Even though the time pattern of ROI could theoretically diverge between present value and the conventional depreciation approaches, it does not necessarily follow that such differences would be encountered in practice. Investment decisions are likely to involve considerations like compatibility with ongoing activities and the strategy of the organizational unit. With such a portfolio perspective, it is the weighted average ROI of an investment package that is of concern. Prior criticisms of conventional ROI, however, have mostly focused on the individual project level. The few studies that have considered portfolio ROI (as it is computed using common accounting procedures) have tended to analyze investments with unrelated cash flows (e.g., Solomon [1966] and Fisher and McGowan [1983]). Further, they have not considered how uncertain cash flows may affect portfolio ROI for ex post performance evaluation. Our computer simulation is aimed at addressing some of these limitations. Below, we first present our methodology, then the results are reported and discussed.

\section{The Simulation Methodology}

Our simulation focused on three factors: degree of cash flow uncertainty, extent of interdependency among projects, and growth rate. First, we took the project illustrated in Figure 1 and made the three cash inflows uncertain, with a normal distribution of mean $\$ \mathrm{M}$ and standard deviation $\$ S$, where $\$ S$ was $\$ 2,500$ and $\$ 1,000$ in alternate sets of simulations. $\$ M$ was held constant at $\$ 10,000$ in the no-growth case. In alternate sets of simulation runs, annual growth rates of 5,10 , and 20 percent were used.

A second project was created from the first, with the same cash flow characteristics, except 
that the inflows to the second project were correlated with the same-period inflows from the first. The correlation coefficient between the two projects' same period cash flows were $+.5,0$, and -.5 in alternate simulation runs.

ln all, 24 sets of simulations were run (30 times each) using all possible combinations of the following values:(7)

Standard deviation: $\$ 1,000 ; \$ 2,500$

Growth rate: $0 \% ; 5 \% ; 10 \% ; 20 \%$

Correlation coefficient: .5; $0 ;-.5$

Since each project has a 3-period life, the size of the investment portfolio stabilized at six projects - we started out with two projects, and added two more at the end of each subsequent period. But starting with the end of period three, two existing projects would expire each period, to be replaced by two new ones. Since the steady-state case is probably more representative of an ongoing firm or division, our analysis focuses on the end-of-period-three results.

\section{Results}

Each simulated project's ROI was computed in turn using straight line, present value, and double declining balance depreciation. Table 1 reports the means and standard deviations of the resulting portfolio ROls for different uncertaintycorrelation-growth-rate combinations.

T-tests for differences in means were applied between each conventional depreciation method and present value depreciation. Significant differences (at the .05 level) are indicated by asterisks. Table 1 indicates significant differences between straight line and present value depreciation only when the projects are unrelated. As discussed previously, prior studies have only considered independent projects, and our finding is consistent with their results for such settings. Our finding of no significant differences for projects with inter-related cash flows is new; it suggests that in organizations with focused investment strategies, the benefits from adopting the more costly present value depreciation ap- proach may be limited. Given the limited scope of the computer simulation, this conclusion can only be a tentative one. However, it does suggest the need for further work in this direction.

The tests of double declining balance versus present value depreciation indicate significant differences in almost every case. Together with the straight line results, this finding suggests that the potential benefits from present value depreciation depends both on a firm's investment opportunities and financial reporting method. As reported earlier, 67 percent of the Compustat firms used straight line depreciation exclusively, and a further 29 percent used this method to some extent. Thus, many firms may not have adopted present value depreciation because their existing reporting methods already provided about the same information at much lower cost.

\section{Summary}

This paper has suggested that the adoption of present value depreciation can involve significant implementation costs, but with only limited potential benefits in some cases. Hence, business firms' non-adoption of this theoretically superior technique may be economically sound. A limitation of the simulation results is the small range of scenarios and parameters. Future research to assess the robustness of these findings would be highly desirable.

\section{Footnotes}

1 Reece and Cool [1978] report that 85 percent of their respondents calculate ROI based on net book value.

2 This data base is on computer tape and contains financial report information for about 2,000 firms listed on the New York and American Stock Exchanges.

3 Taylor [1923] and Hotelling [1925] were early proponents of this approach.

4 None of Reece and Cool's respondents explicitly indicated use of present value depreciation. 
Table 1

Means and Standard Deviations of Simulated Portfolio ROIs for the Steady-State Portfolio Size

(Standard deviations in parentheses)

\begin{tabular}{|c|c|c|c|c|c|}
\hline \multirow{2}{*}{$\begin{array}{l}\text { Depreciation } \\
\text { Method }\end{array}$} & \multirow{2}{*}{$\begin{array}{l}\text { Correlation } \\
\text { Coefficient }\end{array}$} & \multicolumn{4}{|c|}{ Growth/Inflation Rate } \\
\hline & & $0 \%$ & $5 \%$ & $10 \%$ & $20 \%$ \\
\hline \multirow{3}{*}{ Straight-line } & -.5 & $\begin{array}{l}20.58 \\
(4.210\end{array}$ & $\begin{array}{l}21.04 \\
(4.26)\end{array}$ & $\begin{array}{l}20.16 \\
(4.20)\end{array}$ & $\begin{array}{l}20.65 \\
(5.26)\end{array}$ \\
\hline & 0 & $\begin{array}{c}23.73^{*} \\
(6.43)\end{array}$ & $\begin{array}{l}22.68 \\
(6.95)\end{array}$ & $\begin{array}{c}21.01^{*} \\
(6.83)\end{array}$ & $\begin{array}{l}21.09 \\
(6.87)\end{array}$ \\
\hline & +.5 & $\begin{array}{l}21.17 \\
(7.02)\end{array}$ & $\begin{array}{l}21.13 \\
(7.68)\end{array}$ & $\begin{array}{l}19.55 \\
(7.66)\end{array}$ & $\begin{array}{l}21.83 \\
(9.27)\end{array}$ \\
\hline \multirow{3}{*}{ Present value } & -.5 & $\begin{array}{l}20.92 \\
(5.68)\end{array}$ & $\begin{array}{l}20.51 \\
(4.13)\end{array}$ & $\begin{array}{l}18.64 \\
(5.36)\end{array}$ & $\begin{array}{l}19.84 \\
(3.97)\end{array}$ \\
\hline & 0 & $\begin{array}{l}19.32 \\
(6.06)\end{array}$ & $\begin{array}{l}22.75 \\
(4.65)\end{array}$ & $\begin{array}{l}17.27 \\
(5.64)\end{array}$ & $\begin{array}{l}19.80 \\
(6.60)\end{array}$ \\
\hline & +.5 & $\begin{array}{l}20.36 \\
(8.12)\end{array}$ & $\begin{array}{l}17.85 \\
(9.52)\end{array}$ & $\begin{array}{l}19.97 \\
(7.27)\end{array}$ & $\begin{array}{l}22.30 \\
(8.72)\end{array}$ \\
\hline \multirow{3}{*}{$\begin{array}{l}\text { Double-declining } \\
\text { balance }\end{array}$} & -.5 & $\begin{array}{c}27.21^{*} \\
(7.48)\end{array}$ & $\begin{array}{l}26.90^{*} \\
(5.29)\end{array}$ & $\begin{array}{l}25.75 \\
(5.59)\end{array}$ & $\begin{array}{l}22.33 \\
(7.46)\end{array}$ \\
\hline & 0 & $\begin{array}{c}29.30^{*} \\
(9.04)\end{array}$ & $\begin{array}{l}27.02^{*} \\
(9.11)\end{array}$ & $\begin{array}{c}22.36^{*} \\
(8.28)\end{array}$ & $\begin{array}{l}18.89 \\
(7.77)\end{array}$ \\
\hline & +.5 & $\begin{array}{c}32.86^{*} \\
(11.60)\end{array}$ & $\begin{array}{c}27.95^{*} \\
(11.78)\end{array}$ & $\begin{array}{l}26.49 \\
(8.92)\end{array}$ & $\begin{array}{l}20.42 \\
(9.74)\end{array}$ \\
\hline
\end{tabular}

Note: *Significantly different from the corresponding ROI under present value depreciation at the .05 level under a $t$-test. 
On the other hand, 92 percent of them reported using the same depreciation method as that employed in external financial reporting.

5 Gitman and Goodwin [1979] surveyed 150 firms from the Fortune 1000. They report that 79 percent of these respondents prepared cash forecasts manually.

6 If the objective is to motivate the optimal selection of individual investment projects, then tracking project-specific cash flows are necessary. If monitoring is on a portfolio basis (e.g., the division as a unit), then this problem is lessened, but the problems of treating "forecast errors" would remain.

7 The simulation technique is described in Naylor et al [1966, pp. 97-99]. Only the results for the case standard deviation $=\$ 2,500$ are presented. Those for a standard deviation of $\$ 1,000$ were not qualitatively different.

\section{References}

1 Anthony, R., J. Dearden and N. Bedford, Management Control Systems(5th ed.) (Irwin, 1984).

2 Fisher, F. and J. McGowan, "On the Misuse of Accounting Rates of Return to Infer Monopoly Profits," The American Economic Review (March 1983), pp. 82-97.

3 Gitman, L. and M. Goodwin, "An Assessment of Marketable Securities Management Practices," The Journal of Financial Research (Fall 1979), pp. 161-169.

4 Hotelling, H., "A General Mathematical Theory of Depreciation," Journal of the American Statistical Association (September 1925), pp. 340-353.

5 Johnson, H. and R. Kaplan, Relevance Lost: The Rise and Fall of Management Accounting (Harvard Business School Press, 1987).

$6 \quad$ Kaplan, R., Advanced Management Accounting (Prentice-Hall, 1982).

7 ------, "Measuring Manufacturing Performance: A New Challenge For Managerial Accounting Research," The Accounting Review (October 1983), pp. 686-705.

8 Mauriel, J. and R. Anthony, "Misevaluation of Investment Center Performance," Harvard Business Review (March-April 1966).

9 Naylor, T., J. Balintfy, D. Burdick and K. Chu, Computer Simulation Techniques (Wiley, 1966).

10 Reece, J. and W. Cool, "Measuring Investment Center Performance," Harvard Business Review (May-June, 1978).

11 Solomon, E., "Return on Investment: The Relation of Book-Yield to True Yield," Research in Accounting Measurement (The American Accounting Association, 1966), pp. 232-244.

12 Taylor, J., "A Statistical Theory of Depreciation," Journal of the American Statistical Association (December 1923), pp. 1010-1023. 